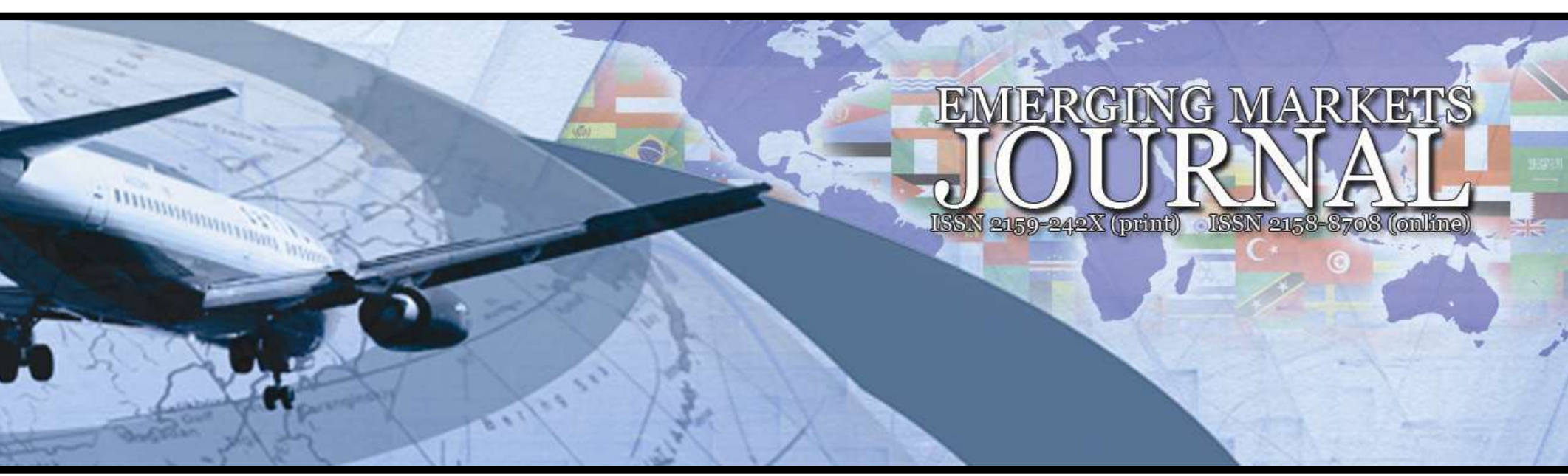

\title{
IMPACT OF THE GLOBAL CRISIS ON THE GOVERNANCE STRUCTURES OF INTERNATIONAL FINANCIAL INSTITUTIONS
}

\author{
Gökhan Özkan \\ Yalova University | e-mail: ozkan.gkhnn@gmail.com
}

Volume 1 (2011) | ISSN 2158-8708 (online) ｜ DOI 10.5195/emaj.2011.9 | http://emaj.pitt.edu

Abstract

The global financial crisis dragged many countries into recession, demonstrated that the international financial system has structural problems and started discussions about restructuring of the international financial institutions. The main objective of this paper is to investigate the impact of the global financial crisis on the governance structures of the international financial institutions. To this end, studies made at different international platforms were evaluated. The debates and negotiations among the developed and developing countries about governance structures of the international financial institutions were analyzed. Developing countries' demand to reform the decision-making mechanisms of the Bretton Woods institutions, the IMF and the World Bank and developed countries' reservations were investigated. It was concluded that the new shape of the international financial architecture and governance structures of international financial institutions will depend on international politics as well as the evolution of the global crisis and the economic dynamics.

Keywords: Governance structures, international financial institutions, global crisis, international politics

\section{(cc) BY-NC-ND}

This work is licensed under a Creative Commons Attribution-Noncommercial-No Derivative

Works 3.0 United States License.

\section{UILIS

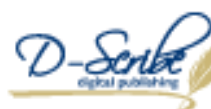

This journal is published by the University Library System of the University of Pittsburgh as part

of its $\underline{\mathrm{D}-\text { Scribe Digital Publishing Program, and is cosponsored by the University of Pittsburgh Press }}$ 


\section{Impact Of The Global Crisis On The Governance Structures Of International Financial Institutions}

\author{
Gökhan Özkan
}

\section{Introduction}

In recent years there has been a pressure from At the Bretton Woods Conferences in 1944, international monetary system was determined as adjustable peg system tied to the U.S. dollar and gold, the IMF and the World Bank were established, and the Bretton Woods System was constituted. After the collapse of the Bretton Woods System in 1971; volatility in exchange rates, technological innovation, which has accelerated economic integration through virtual and physical time-space compression (Harvey, 1989), and financial liberalization reforms, which led to an increase in levels of capital account openness and financial openness, (Walter and Sen, 2008: 122) increased and accelerated international capital movements and many developed and developing countries entered into financial crises.

The global financial crisis, which started in the U.S., is the last and the largest of these crises. Because of the degree of globalization in financial markets, global crisis quickly spread to other countries. (Yunus, 2009: 6) The globalization of capital has been an integral part of the scale of the financial crisis. (Legg and Harris, 2009: 369) The global crisis started discussions about the restructuring of the international financial system. Some scholars argue that significant transnational regulatory initiatives will advance as a result of the financial crisis. In the contrary, some scholars think the crisis is generating a reassertion of state authority over international financial markets. (Helleiner, 2009a:1) Nonetheless, it is generally accepted that international financial architecture, which is likened to oil in our cars that lubricates the engine of world growth (El-Arian, 2009:88), is far from preventing crises.

The developed countries, particularly the G-7 countries and the developing countries, particularly the BRIC countries (Brazil, Russia, India and China) tried to shape the restructuring process of the international financial system and the international financial institutions according to their interests. Divergence between the perspectives of developed and developing countries transformed the restructuring process into a political process. It is expected that besides accelerating the restructuring of the international financial system, the financial crisis will have geopolitical reflections (Burrows and Harris, 2009) and the international balance of power will find a new equilibrium because of the crisis. (Germain, 2009) This paper aims to investigate the impact of the global financial crisis on the governance structures of the international financial institutions within context of international politics. The article proceeds in the following manner. First, impact of the global financial crisis on the restructuring of the international financial system is examined. In the second section, role of the G-20 summits and international politics on the restructuring process is analyzed. In the third section, restructuring of the international financial institutions' governance is evaluated. 


\section{THE GLOBAL CRISIS} AND THE INTERNATIONAL FINANCIAL SYSTEM

The biggest financial crisis since the Great Depression, which originated in the US and spread quickly to other countries, clearly demonstrated that the U.S. and international financial architecture has structural flaws so that this is not just a crisis in the system, this is a crisis of the system. The crisis was a challenge; the three of the most seemingly effective international institutions (the World Trade Organization, the IMF, and the international network of regulatory agencies) failed to meet. (Zaring, 2010: 475)

Global financial crisis demonstrated that nations are still the most important actors of the international financial system. It was also clearly seen that G-7 countries cannot decide on global economic issues themselves; representation and participation of emerging countries in the decisiontaking mechanisms is needed. The crisis moved the center of gravity of the international economy towards emerging countries and the G-20 emerged as the legitimate platform to restructure the international financial architecture in terms of representation, international reserves and economic power. (Bradford, 2009: 38) The G-20 countries together represent over 85 percent of world GDP, 80 percent of world trade, and two-thirds of the world's population. (Beeson and Bell, 2009:68) In this connection, creation of the G-20 increases the possibility of effective policy coordination and increase the credibility and legitimacy. (Germain, 2001)

The global crisis also showed that the international financial system has expanded greatly in size, reach and liquidity and gained the potential to drag not only the developing but also the developed countries into crisis. (Wade, 2008) Even if the international institutional framework for international finance is seen as the most sophisticated of the global governance regimes (Kerwer, 2005), the crisis showed that the systemic complexities of the 21 st century networks should be better understood. (Schweitzer et al., 2009) The international financial system has become so integrated and the global economy so interdependent that policy coordination at the global level is needed and to do that, international institutions must be reformed in a way that gives greater voice and representation to the emerging countries. (Pisani-Ferry and Santos, 2009:12)

According to the IMF study (2009), synchronized recessions after financial crises tend to be deeper and last longer, which makes coordinated action and cooperation at the global level more urgent. As a result, the global governance concept, which is related to the emerging urgent global problems that cannot be solved by the national instruments of decision making, (Potucek, 2009: 12) is pronounced more and more frequently. It is argued that a comprehensive supervisory and regulatory regime that monitors and assess systemic financial risks stemming from the poor corporate governance, riskmanagement and management of liquidity risk of all the banks and the shadow financial system should be constructed. Absence of binding international standards to enhance financial transparency and accountability (Abdelal, 2007) is seen as one of the most important factors that intensified the global financial crisis.

It is argued that financial deregulation reforms, which opened up countries to the free flow of capital in and out of them, removed the regulations on financial institutions operating within countries, and removed the political controls from the Central Bank, made the financial sectors of nations parts of the international financial sector and increased countries' vulnerabilities. (Beder, 2009: 18) Nonetheless, there are also views that worldwide drive to regulation is misconceived. (Connolly, 2009:422) 
Even if the need for cooperation at the global level was clearly recognized, it was also seen that states are not ready for a global financial regulator and a central bank. In spite of the fact that a supranational regulator and international lender of last resort may be functional to stabilize international financial markets, it is also accepted that it is not easy to establish these institutions under current circumstances. So, until these kinds of supranational institutions are established, intensifying national regulations, enhancing international cooperation and redesigning the regulatory framework at the national and international levels are seen as short and middleterm options. It is expected that IMF will continue to play the role of "quasi-lender of last resort".

\section{III.THE G-20 SUMMITS, INTERNATIONAL POLITICS AND THE RESTRUCTURING PROCESS}

As the global crisis deepened in the first quarter of 2009, need for cooperation at the global level was clearly understood. Nevertheless, developed and developing countries, with different points of view about the restructuring process, tried to shape the process according to their interests. The restructuring process turned into a political dispute among the developed and developing countries.

G-20 meetings symbolized the changing balance of power in the international economy. (Bradford, 2009:38) Prior to the crisis, the G-7 summits were platforms where the most important decisions about the international economic order were taken. Nonetheless, the global financial crisis necessitated more participation and representation of the developing countries. G-20 reflected the structural shifts in the system hereby power balances are being altered by the rise of emerging countries, particularly the BRIC countries (Brazil,
Russia, India and China). (Armijo, 2007) "The BRIC countries" concept gained a political meaning rather than a just economic term. Putin had mentioned this in his Munich speech in 2007: "There is no reason to doubt that the economic potential of the new centers of global economic growth (the BRICs) will inevitably be converted into political influence and will strengthen multipolarity" (Lukyanov, 2009:130)

G-20 is seen as an important step towards a reformed global economic governance regime. (Schmidt et al., 2009) Nonetheless, it is also argued that since G-20 is merely a gathering of national leaders, not a formally constituted international organization and lacks the capacity to enforce its decisions, it does not result in any fundamental changes to the system. (Buckley, 2010) G-20 is likened to a non executive board of directors for the global system of governance than an executive management committee. (Garrett, 2010: 38) G-20 declarations are also criticized on the basis that no preconditions are defined for more cooperation and no underlying principles are defined. (Graaf and Williams, 2009: 414)

During the initial phases of the crisis, in November 2008, the G-20 countries convened with the agenda of taking measures to prevent the deepening of the crisis. G-20 countries convened again in April 2009 and took important decisions. Finally, at the G-20 meeting in September 2009, the leaders declared that the G-20 became the main platform for international economic cooperation.

G-20 meeting in April 2009 was successful at some extent. Nonetheless, the meeting failed to reform the international financial system because of clash of interests among the AngloSaxons, the Europeans and the emerging countries. It is argued that the US blocked the reform of the international financial system and pushed for global fiscal stimulus. The Europeans resisted fiscal stimulus and reform of the IMF and the World Bank since their voting power would be cut to create space for the emerging countries. They shifted the 
focus from these issues to the regulatory reforms. Meanwhile, emerging countries, particularly BRIC countries stressed the importance of the reform of the international financial and monetary system.

At the end of the summit, it was declared that IMF's financial resources were increased threefold to $\$ 750$ billion, which was seen useful to help stabilize financial sector in troubled regions of the world. (Yunus, 2009:7) Nonetheless, most of this amount consisted of commitments. Only Japan signed a $\$ 100$ billion bilateral barrowing agreement with the IMF. The E.U. and the U.S. committed $\$ 100$ billion. China pledged to buy $\$ 50$ billion IMF bonds denominated in SDRs. Russia, Brazil, South Korea and India also pledged to buy $\$ 10$ billion IMF bonds. Canada and Switzerland also committed $\$ 10$ billion dollar. Adding commitments of other countries, the total amount amounted to 423 billion dollars by early September. The European Union increased its commitments by 78 billion dollars in September 2009 and in this way the $\$ 500$ billion target could be reached before the G-20 summit at the end of the September.

The G-20 meeting in April 2009 was not successful especially from developing countries' perspectives in terms of reform of the international financial system. Russia voiced its concerns with regards to the problems caused by the dominance of dollar and China, which is expected to provide more resources to the IMF, proposed the reform of the international financial system with specific suggestions; nonetheless G-7 countries simply ignored. (Stewart, 2009) It is argued China pledged to buy only $\$ 50$ billion IMF bond rather than giving long-term loan to give a massage that it wants faster reforms in decision-making mechanisms of the IMF. (The Economist, 2009: 79) Other BRIC countries also refused to participate in the New Arrangements to Borrow (NAB) or special arrangements, rather offered to purchase IMF bonds. (Woods,

2010: 59) Even if fundamental reforms such as the rearrangement the quota system was postponed, some substantial changes were made such as trebling of IMF's financial resources to $\$ 750$ billion, a \$250 billion dollar increase in the Special Drawing Rights (SDR), a new facility called Flexible Credit Line (FCL), a change of conditionality that would let barrower countries to keep up social spending during crises, a doubling of the limit on the total amount each member country can barrow, softening of the core conditionality, better surveillance of risks created by individual countries to the international financial system, a change in the selection of managing directors towards merit-based process. (Weissman, 2009:11) Grabel (2010: 12) argues that G-20 representatives gave the IMF pride of place in global efforts to respond to the crisis. The G-20 countries also agreed to reshape regulatory systems, to extend regulation and oversight to all systemically important financial institutions, instruments and markets. They decided to strengthen international cooperation by establishing the remaining supervisory colleges for significant cross-border firms by June 2009, building in the 28 already in place; by implementing the FSF principles for cross-border crisis management immediately.

Members of the IMF met at the annual IMF meeting in the last week of April and discussed how they will raise the funds that were agreed upon at the G-20 summit. They also discussed the reform of the decisionmaking mechanisms of the IMF and the World Bank. Developing countries were not convinced that IMF's more powerful countries were serious about ceding any control. They warned that they would not provide financial resources without having more voice in the decision-making process. (Prosser, 2009)

Alexei Kudrin, Russia’s finance minister, said at the meeting that, "we already meet a cool attitude and even resistance to reform the IMF. The leading countries are not in a hurry... this was the main discussion, the nerve of the meeting." Brazilian finance minister stated that contributions made by the developing countries would be provisional, meaning that they may be withdrawn if 
the IMF's decision-making process is not reformed. From the initial phases of the global crisis, BRIC countries tried to increase their influence in the restructuring process. In March 2009, before the G20 summit, BRIC countries came together and issued their first communiqué. In this communiqué, they called attention to the reform of the international financial institutions. Taking into consideration the growing weights of the emerging countries in the global economy, they wanted reconsideration of the quotas and voting rights of the IMF and the World Bank. They wanted the reform of the international monetary system. BRIC countries came together again in June and issued another communiqué. Similar to their March communiqué, they called for the reform of the international financial and monetary system. They called for a more diversified monetary system. They also called for a multipolar international system based on international law, equality, mutual respect, cooperation, coordinated action and collective decision-making principles. On June 29, 2009, the United Nations ratified an action plan about the international financial system, according to which the member countries demanded an immediate reform of the Bretton Woods institutions.

BRIC countries continued to criticize the international financial and monetary architecture at other platforms. At the G-8 summit held in July, China repeated its demand for a rational and more diversified international monetary system. Russia also argued that an alternative global reserve currency should be included in the agenda of the G8 summit.

The United Nations Trade and Development Conference supported BRIC countries' arguments about the international financial and monetary system with a report in September. (UNCTAD, 2009:10-13) According to arguments in report, dollar should be replaced with another international reserve currency issued by an international organization. It was argued that restructuring of the international financial system in this way would eliminate the problem of instability creating capital movements and would decrease speculation. The report specifically emphasized the SDR. It was argued that the SDRs could function as supranational reserve currency. Meanwhile, some scholars argue that since the purchasing power of the SDRs is uncertain and since their liquidity is relatively insufficient, they are not suitable for countries with balance of payments surplus. (McKinnon, 2009:7)

Finance ministers of the BRIC countries came together in September before the G-20 summit issued a declaration and reiterated their demands about the reform of the international financial and monetary system.

They stated that the most serious problem that damages the legitimacy of the IMF and the World Bank is unjust distribution of quotas and voting rights. They demanded a seven percent quota shift from developed countries to developing countries in the IMF and a six percent voting rights shift in the World Bank. They called for a more stable and predictable monetary system. They also demanded a transparent selection process for the IMF and World Bank Presidents based on the merit, not on the nationality.

G-20 summit in September has been a summit, which concrete results emerged from ongoing negotiations and discussions among the developing and developed countries in different platforms since the beginning of the global crisis. The leaders declared that the G-20 has become the main platform of international economic cooperation.

Developing countries', particularly BRIC countries' demands for the reform of the international monetary and financial system were met at some extent. At the G-20 summit, a shift of five percent quota shares from overrepresented developed countries to underrepresented developing countries in the IMF and three percent voting rights shift in the World Bank were agreed upon. 
Other important decisions about the international financial system were also taken. The G-20 leaders agreed to launch framework for strong, sustainable, and balanced growth. They agreed to address critical issues such as the size and composition of the Executive Board and ways of enhancing its effectiveness, the Fund Governors' involvement in the strategic oversight of the IMF, enhancing staff diversity and making the appointments of the heads and senior leadership of all international institutions through a transparent and merit-based process.

The G-20 also agreed to reconsider the regulation system for banks and other financial institutions in a way that prevents excesses that lead to financial crisis, to improve international standards for bank capital, to make necessary arrangements about compensation to end practices that lead to excessive risk-taking, to make the overthe-counter (OTC) derivatives more transparent, to regulate and supervise the hedge funds and credit rating agencies, and to make the regulatory and supervisory arrangements for the systematically important international financial institutions.

At the IMF-World Bank Annual Meetings held in Istanbul in October 2009, decisions that support and complement the decisions taken at the G-20 summit were taken. These "Istanbul Decisions" include:

1. Enlarging the mandate of the IMF in a way that includes all macroeconomic and financial policies, which affect the global stability.

2. Providing insurance to more countries as the lender of last resort by using Flexible Credit Line.

3. To expand the multilateral surveillance authority of the IMF.

4. To shift a quota share of at least five percent from developed countries to developing countries.

\section{IV.RESTRUCTURING THE GOVERNANCE OF THE INTERNATIONAL FINANCIAL INSTITUTIONS}

Confidence to the international financial system diminished significantly as a result of the global financial crisis. It is argued that transparency and public accountability of international financial institutions and new complex financial instruments should be augmented to reestablish confidence to the financial system. (Porter, 2009:8)

Since the world is not ready for a brandnew global financial regulator or a central bank after the global crisis, it is estimated that the global financial crisis will possibly lead to the restructuring of the international financial system in a way that enhances IMF's role in the global economy. The decision to increase IMF's financial resources at the G-20 meeting in April 2009 reflects increasing importance of the IMF.

IMF's role was being discussed extensively before the crisis. The Fund was searching for a way to stay in business. (Weissman, 2009:11) The Fund had cut staff by about 13 percent but still faced a $\$ 300$ million deficit over the next four years in 2008. (Griesgraber, 2009: 179) There were few countries that had signed stand-by agreements with the IMF in 2000s and it was argued that the Fund could not even find money for its day-to-day activities. Bank of England Governor Mervyn King (2006) had said this:"The Fund's remit is unclear. Its lending activities have waned and its role in the international monetary system is obscure."

The global crisis changed international economic prospect for the IMF fundamentally. It rescued the institution from its increasing irrelevance. (Chorev and Babb, 2009) Nonetheless, to be a legitimate and effective institution, it is 
argued that reforms must be implemented in four main areas including governance, economic philosophy, IMF staff competencies and substantial increase in financing. (Griesgraber, 2009: 180-183)

The other institution that will probably gain importance is the Financial Stability Forum. The FSF was transformed at the G-20 meeting in April 2009 into the Financial Stability Board. The G20 placed the FSB at the centre of intensified regulatory cooperation. (Arner and Taylor, 2009: 489) It includes all G20 countries, FSF members, Spain and the European Commission. The FSB will collaborate with the IMF to provide early warning of macroeconomic and financial risks and the actions needed to address them. Financial Stability Board was given important roles with regards to the international financial system such as:

1) Assessing the weak points of the financial system and identifying the steps to address them. Facilitating and enhancing co-ordination among the authorities responsible for the financial stability.

2) Providing the regulatory policy recommendations about the market developments and their implications.

3) Monitoring and assessing the practice of regulatory standards. Monitoring the policy development work of International Standard Setting Bodies and ensuring that their work is coordinated and focused on priorities and addressing gaps.

4) Promoting contingency planning for cross-border systemic crisis management. Conducting Early Warning Exercises in collaboration with IMF to identify the buildup of macroeconomic and financial risks.

5) Establishing a supervisory college to monitor the systematically important international financial firms Overseeing all systemically important financial institutions, instruments and markets including the hedge funds, which will have to register and report their strategy, debt and risk levels.
6) Establishing a clearing house, through which credit derivatives, whose value is derived from an underlying asset, will be cleared.

It is expected that FSB will have an important role in the restructuring process of the international financial system and will function like a global financial regulator.

Decision-making mechanisms of the international financial institutions such as IMF and World Bank are among the most critical and controversial issues of the restructuring process. Developing countries demand larger quota shares and voting rights arguing that they are underrepresented.

The U.S. has 17,09 percent quota share in the IMF. This gives the US the veto power over crucial decisions since a majority of 85 percent is required. The European Union countries have 32,09 percent quota share while China has 3,72 percent, Russia 2,73 percent, India 1,91 percent and Brazil 1,4 percent. According to experts, the recalculating quota is very slow because of political dynamics. It took very long negotiations for China to be awarded a "special" quota increase when it reabsorbed Hong Kong. In 2008, Board of Governors agreed to a process of change of quotas in small magnitudes. According to the agreement, US's quotas would eventually reduce to 16,73 percent, while China's quota would increase to 3,81 , India's to 2,34 and Russia's to 2,39 .

Especially in recent decades, there has been a shift in the international economic balance of power towards east. This shift was not reflected in the quota shares and the voting rights of the IMF and the World Bank, which limited China's contribution to the new financial resources for the IMF. It is argued that China has pledged to buy only $\$ 50$ billion IMF bonds since its calls for greater representation were not met. It is also argued that China preferred to buy IMF bonds rather than providing long-term financial sources to IMF to show that it wants acceleration of the restructuring process of decision-taking mechanisms of the IMF 
and the World Bank. (The Economist, 2009: 79) In this connection, an expanded role for China in multilateral financial institutions is seen helpful for China's cooperation with regards to the global financial crisis. (Prasad, 2009:233)

IMF's functions were determined in the Bretton Woods Articles of Agreement in 1944 and they were in harmony with the post-war conditions and with the preferences of the politically strongest countries, the US and the UK. (Helleiner, 2009b: 191) Its functions started to change in 1970 s with the transformation of the international financial system. The US suspended the convertibility of the dollar to gold and the Bretton Woods system collapsed. Technological developments, increasing mobility of capital, financial liberalization and deregulation gave the capital movements the potential to drag countries into financial instabilities and crises. IMF's main function transformed from providing balance of payments support to liquidity crisis management. IMF signed agreements with many countries most of which were not successful. It was particularly criticized for its policies after the Asian crises in 1997-98. In the first years of the 21st century, IMF's role seemed to diminish as less and less countries signed agreements with IMF.

The global financial crisis changed this picture totally. IMF became almost the most important international institution of the international economy. IMF's financial resources were increased to $\$ 750$ billion. New facilities such as Short-term Liquidity Facility (SLF), which provide more flexibility, were created. With ShortTerm Liquidity Facility (SLF), IMF will be able to channel funds quickly to eligible emerging markets with sound policies and sustainable debt burdens. It is expected that as IMF's effectiveness and influence in the international economy increase, reform of its decision-taking mechanism will be a more important issue. Appointment process of the IMF and World Bank Presidents is criticized. It is argued that the IMF and World Bank Presidents are selected according to an informal agreement among the U.S. and the West European countries and as a consequence, all of the ten IMF Presidents since the establishment of both institutions were West European nationals while all of the eleven World Bank Presidents were U.S. nationals. (Cogan, 2009: 209)

A critical issue with regards to the governance of IMF is the degree of control of the staff and management by the Executive Board. There may sometimes be conflicts of interest between the staff focusing on global public goods and the Executive Board that is controlled politically by member states, particularly ones with the larger quotas. It is argued that if there is no change in the structure of the executive board, the Fund's effectiveness in providing a high-level forum for international economic cooperation will decrease. (Thimann, Just and Ritter, 2009: 188)

\section{CONCLUSION}

The global financial crisis demonstrated that the international financial architecture has structural flaws. From the beginning of the crisis, debates and negotiations about restructuring of the international financial system and the governance of the international financial institutions continued in different platforms. Since the international financial system is a complex system which consists of various institutions, rules and regulations; it is expected that the restructuring process will be a slow process.

Apart from the difficulties of the restructuring process stemming from economic factors and the complexity of the international financial system, there are also political dynamics that affect, slow down and harden the process. Developing and developed countries have different perspectives and different political concerns about the governance structures of international financial institutions. Developing countries want the reform of the decision-making mechanisms of the IMF and World 
Bank in a way that increases the quota shares and voting rights of the developing countries.

Negotiations and debates among the developed countries, particularly the G-7 countries and the developing countries, particularly the BRIC countries continued in different platforms since the beginning of the global financial crisis. Political agendas shaped the restructuring process as much as the economic concerns. The result was that along with the regulatory reforms, reforms about the decision-making process of the IMF and the World Bank were made in a way that gives more voice to the developing countries in the international financial institutions.

It is expected that developed countries will try to slow down the restructuring process since their control on the decision-making processes of the IMF and the World Bank provides them various economic and political advantages. Nonetheless, since they also recognize that international economic balance of power has changed in recent decades, they may accept some transfer of control. Decisions taken at the G-20 summit in September 2009, according to which IMF quota shares and World Bank voting rights will be transferred from developed countries to developing countries, can be seen as a first step towards greater role of developing countries in the international financial system.

Meanwhile, the developing countries, particularly the BRIC countries, will probably press for faster reforms in the decision-taking mechanisms of the IMF and the World Bank. They will try to increase the amount of IMF quota shares and the World Bank voting rights that will be transferred to them. It is anticipated that the restructuring process will proceed slowly because of the complex relations between the international financial system and the international politics. 


\section{References}

1. Abdelal, Rawi (2007), Capital Rules: The Construction of Global Finance, Cambridge, MA: Harvard University Press.

2. Armijo, Leslie E. (2007), “The BRICs Countries (Brazil, Russia, India, and China) as Analytical Category: Mirage or Insight?", Asian Perspective, 31(4): 7-42.

3. Arner, Douglas W. and Taylor, Michael W. (2009), "The Global Financial Crisis and the Financial Stability Board: Hardening the Soft Law of International Financial Regulation”, University of New South Wales Law Journal, 32 (2): 488-513.

4. Beder, Sharon (2009), "Neoliberalism and the Global Financial Crisis", Social Alternatives, 28 (1): 17-21.

5. Beeson, Mark and Bell, Stephen (2009), "The G-20 and International Economic Governance: Hegemony, Collectivism, or Both", Global Governance, 15 (1): 67-86.

6. Bradford, Colin I. (2009), "The G-20 Financial Summit: A New Day for Global Governance”, Current, January 2009: 38-39.

7. Buckley, Ross (2010), "Resilience and Global Financial Governance", University of New South Wales Faculty of Law Research Series Paper 13, at http://law.bepress.com/unswwps/flrps10/art13. (07.04.2010)

8. Burrows, Mathew J. and Harris, Jennifer (2009), "Revisiting the Future: Geopolitical Effects of the Financial Crisis", The Washington Quarterly, 32(2): 27-38.

9. Chorev, Nitsan and Babb, Sarah (2009), "The Crisis of Neoliberalism and the Future of International Institutions: A Comparison of the IMF and the WTO", Theory and Society, 38 (5): 459-484.

10. Cogan, Jacob K. (2009), "Representation and Power in International Organization: The Operational Constitution and its Critics", The American Journal of International Law, 103 (2): 209-263.

11. Connolly, Bernard (2009), "Regulation: Reform or Revenge? The Crisis, the EU and British Financial Markets”, Law \& Financial Markets Review, 3 (5): 414-424.

12. El-Erian, Mohamed A. (2009), “Shrinkage”, Foreign Policy, 172, p. 88.

13. Garrett, Geoffrey (2010), “G2 in G20: China, The United States and the World after the Global Financial Crisis”, Global Policy, 1 (1): 29-39.

14. Germain, Randall D. (2001), "Global Financial Governance and the Problem of Inclusion”, Global Governance, 7 (4): 411-426.

15. Germain, Randall D. (2009), "Financial Order and World Politics: Crisis, Change and Continuity", International Affairs, 85(4): 669-687. 
16. Graaf, Frank Jan De and Williams, Cynthia A. (2009), “The Intellectual Foundations of the Global Financial Crisis: Analysis and Proposals for Reforms”, UNSW Law Journal, 32 (2): 390-415.

17. Grabel, Ilene. (2010), "Productive Incoherence in an Uncertain World: Financial Governance, Policy Space and Development after the Global Crisis”, Political Economy Research Institute Working Paper No. 214.

18. Griesgraber, Jo Marie (2009), "Reforms for Major New Roles of the International Monetary Fund? The IMF Post-G-20 Summit”, Global Governance, 15 (2): 179-185.

19. Harvey, David (1989), The Condition of Postmodernity: An Enquiry into the Origins of Cultural Change, Oxford: Basil Blackwell

20. Helleiner, Eric (2009a), "Special Forum: Crisis and the Future of Global Financial Governance", Global

21. Governance, 15 (1): 1-2.

22. Helleiner, Eric (2009b), "The Development Mandate of International Institutions: Where Did it Come From," Studies in Comparative International Development, 44 (3): 189-211.

23. IMF (International Monetary Fund) (2009), World Economic Outlook April 2009: Crisis and Recovery, Washington: IMF.

24. Kerwer, Dieter (2005), "Rules the Many Use: Standards and Global Regulation?", Governance: An International Journal of Policy, Administration, and Institutions, 18: 611-632.

25. King, Mervyn (2006), "Reform of the International Monetary Fund", Speech at the Indian Council for Research on International Economic Relations, New Delhi, February, at http://www.bankofengland.co.uk/publications/speeches/2006/speech267.pdf. (24.10.2009)

26. Legg, Michael and Harris, Jason (2009), "How the American Dream Became A Global Nightmare: An Analysis of the Causes of the Global Financial Crisis", UNSW Law Journal, 32 (2): 350-389.

27. Lukyanov, Fyodor (2009), "Putin's Russia: The Quest for a New Place”, Social Research, 76 (1): $117-150$.

28. Mckinnon, Ronald (2009), "Reconsidering SDRs", Harvard International Review, 31(1), p. 7.

29. Pisani-Ferry, Jean and Santos, Indhira (2009), "Reshaping the Global Economy", Finance \& Development, March 2009: 8-12.

30. Porter, Tony (2009), "Why International Institutions Matter in the Global Credit Crisis", Global Governance, 15 (1): 3-8.

31. Potucek, Martin (2009), "Will Global Public Policy Arise from Global Crisis", Central European Journal of Public Policy, 3 (2): 4-21.

32. Prasad, Eswar S. (2009), "Effects of the Financial Crisis on The U.S.-China Economic Relationship," CATO Journal, 29 (2): 223-235. 
33. Prosser, David (2009), "Row with Emerging Nations Threatens IMF's Cash Call”, The Independent, 27 April 2009.

34. Schmidt, Anna; Arancibia, Paz; Kahlon, Rakhil; Komoto, Nobuhiro; Myers, John; Munyi, Mary; Ngororano, Tonaina; Omandi, George and Sepaha, Prabal (2009), "Geopolitics, Global Governance and Crisis Narratives", IDS Bulletin, 40 (5): 89-100.

35. Schweitzer, Frank; Fagiolo, Giorgio; Sornette, Didier; Vega-Redondo, Fernando; Vespignani, Alessandro and White, Douglas R. (2009), “Economic Networks: The New Challenges”, Science, 325: 422-425.

36. Stewart, Heather (2009), “Can the IMF Now Feed the World?”, The Observer, 26 April 2009.

37. The Economist (2009), "Finance and Economics: Promises, Promises; The IMF's Search for Funds", 13 June 2009.

38. Thimann, Christian; Just, Christian and Ritter, Raymond (2009), "Strengthening the Governance of the International Monetary Fund: How a Dual Board Structure Could Raise the Effectiveness and Legitimacy of a Key Global Institution”, Global Governance, 15 (2): 187-193.

39. UNCTAD (United Nations Conference on Trade and Development) (2009), Trade And Development Report Overview, Geneva: United Nations.

40. Wade, Robert (2008), “The First World Debt Crisis of 2007-2010 in Global Perspective”, Challenge, 51 (4): 23-54.

41. Walter, Andrew and Sen, Gautam (2008), Analyzing the Global Political Economy, Princeton: Princeton University Press.

42. Weissman, Robert (2009), “A New Life for the IMF”, Multinational Monitor, 30 (2): 10-13.

43. Woods, Ngaire (2010), “Global Governance after the Financial Crisis: A New Multilateralism or the Last Gasp of the Great Powers?", Global Policy, 1 (1): 51-63.

44. Yunus, Muhammad (2009), "Economic Security for a World in Crisis”, World Policy Journal, 26 (2): 5 -12.

45. Zaring, David T. (2010), “International Institutional Performance in Crisis”, Chicago Journal of International Law, 10 (2): 475-504.

Impact Of The Global Crisis On The Governance Structures Of International Financial Institutions 